Tomasz M. Dąbek OSB

\title{
Odniesienia do osoby i tekstów św. Pawła w Regule św. Benedykta
}

Kończymy rok św. Pawła Apostoła, w którym szczególnie rozważamy jego życie i naukę. Osoby konsekrowane żyjące według Reguły św. Benedykta oraz wszyscy zainteresowani duchowością benedyktyńską mogą poświęcić trochę uwagi refleksji nad tekstami Reguty odnoszącymi się do Apostoła Narodów. Jego grób znajduje się we wspaniałej bazylice, którą od wieków opiekują się mnisi zachowujący Regutę św. Benedykta.

Reguła jako całość w obecnej postaci stanowi normę życia mnichów i mniszek, sióstr oraz oblatów i tych, którzy bez formalnych związków z jakąś wspólnotą benedyktyńską starają się żyć tym duchem. Powstała ona jako wyraz tradycji mniszej, którą Zachód zaczerpnął ze Wschodu, wnosząc w nią swój umiar, praktyczne podejście do życia i do człowieka oraz atmosferę rzymskiej rodziny, w której przełożony zastępuje najlepszego Ojca - Boga.

Przez wieki uważano Regułę św. Benedykta za dzieło pisane od początku do końca przez jednego autora przekazującego owoce własnego doświadczenia i przemyśleń. Osoba i osobowość autora, przez pryzmat których zwykło się oceniać wartość dzieł literackich, plastycznych czy muzycznych, mają jednak w tym wypadku mniejsze znaczenie niż ukazanie prawdy będącej owocem życia i myśli wielu pokoleń, ktokolwiek by ją wyrażał słowem.

W ten sposób trzeba patrzeć na wiele ksiąg biblijnych, zarówno na Pięcioksiąg przypisywany dawniej Mojżeszowi, a powstający etapami w ciągu wielu wieków, jak i na Ewangelie czy Corpus Paulinum, w którym obok tekstów pochodzących bezpośrednio od Apostoła Narodów są też te redagowane przez uczniów w ciągu kilku dziesięcioleci.

Podobnie patrzymy dzisiaj na Regutę św. Benedykta jako bardzo mądre zastawienie mniszej tradycji rozwijanej na Zachodzie pod wpływem ideałów zaczerpniętych ze Wschodu. Znana od dawna, lecz niezbyt szeroko rozpowszechniona anonimowa Reguła Mistrza uchodziła przez wieki za rozszerzenie Reguty św. Benedykta. Bezpośrednio przed II wojną światową o. A. Genestout z opactwa Solesmes przedstawił hipotezę chronologiczne- 
go pierwszeństwa Reguly Mistrza. Pobudziło to wielu do dyskusji i badań, w wyniku których uważa się obecnie tę regułę za starszą. W dużej mierze jest to owoc badań o. A. de Vogüé z opactwa La-pierre-qui-Vire. Ponieważ wiele partii obu reguł wykazuje bardzo daleko idącą zbieżność, zatem św. Benedykt albo korzystał ze starszej reguły w obecnej postaci, albo też ze wspólnego źródła, z którego mądrze czerpał to, co odpowiadało jego koncepcji mniszego i chrześcijańskiego życia.

Powyższe stwierdzenia mają też swoje znaczenie przy rozważaniu i interpretacji sposobów korzystania z Pisma Świętego w Regule św. Benedykta. Są w niej teksty, które można nazwać własnymi, i teksty, zwłaszcza w pierwszej części, bardzo podobne do Reguły Mistrza, w której pierwsza część obejmująca rozdziały $1-10$ nazwana jest „aktem służby serca” (actus militiae cordis - 10,123), następna „porządkiem klasztornym” (ordo monasterii - nazwa ta jest zastosowana w uwadze autora między rozdziałami 10 i 11). Polskie wydanie w serii Źródła Monastyczne zaznacza je tłustym drukiem. Zawarte w nich cytaty biblijne zostały przytoczone jako fragmenty wcześniejszych dzieł - św. Benedyktowi podobały się w całości, niekiedy mógł wprowadzać drobne zmiany.

Reguła powstała w języku łacińskim, zatem cytaty i aluzje biblijne pochodzą też z łacińskich przekładów. Można porównywać je z Wulgatą albo wcześniejszymi wersjami tłumaczeń. Trzeba też pamiętać, że w tamtych czasach na ogół cytowano z pamięci, nie zawsze porównując z dostępnym rękopisem. W cytatach występujących także w Regule Mistrza św. Benedykt niekiedy wprowadzał drobne korekty, aby były bardziej zgodne np. z rzymską wersją Psałterza, podobnie jak pisząc o pieśniach w jutrzni, poleca stosować takie, jakich używa Kościół Rzymski $(13,10)$. W polskich przekładach korzysta się z współczesnej wersji przekładu o. J. Wujka z Wulgaty albo z Biblii Tysiąclecia, $w$ razie potrzeby wprowadzając odpowiednie korekty.

W naszych rozważaniach posłużymy się indeksem odniesień biblijnych z krytycznego wydania E. Hanslika z serii Corpus Scriptorum Ecclesiasticorum Latinorum oraz z polskiej edycji Reguły Mistrza i Reguły św. Benedykta z serii Źródła Monastyczne. Omówimy najpierw odniesienia do osoby Apostoła Narodów oraz podamy statystykę korzystania z jego tekstów, a potem przytoczymy kilka przykładów interpretacji najczęściej stosowanych tekstów Pawłowych w różnych kontekstach Reguły.

\section{Święty Paweł i jego teksty w Regule św. Benedykta}

Samo imię św. Pawła wymienione jest w Regule św. Benedykta dwukrotnie. W prologu czytamy: „Jak nawet Apostoł Paweł niczego sobie nie 
przypisywał ze swego apostołowania, lecz mówił: Z łaski Boga jestem tym, czym jestem. Powiedział także: Kto się chlubi, niech się w Panu chlubi” (por. 31-32, przekład polski za wydaniem w serii Źródła Monastyczne dokonanym przez o. Bernarda Turowicza OSB, RB cytuje 1 Kor 15, 10 i 2 Kor 10, 17, tekst odpowiada we wstępie do Reguty Mistrza w komentarzu do Psalmów wersetom 27-28, w RM w drugim wypadku zacytowany tam jest inny Pawłowy tekst o podobnym znaczeniu: „jeśli się trzeba chlubić (to) mi nie wypada" - 2 Kor 12, 2).

Drugi raz św. Paweł jest wymieniony w rozdziale o pokorze przy czwartym stopniu: „Z Apostołem Pawłem znoszą fałszywych braci i błogosławią złorzeczącym" (7, 43, co odpowiada RM 10, 60). W obu wypadkach są to wcześniejsze teksty, świadectwa tradycji mniszej powołującej się na św. Pawła jako na przykład pokory, cierpliwości, gotowości do przebaczenia. W pierwszym św. Benedykt zastosował inny tekst, chciałoby się powiedzieć bardziej teologiczny, w którym św. Paweł nie tylko stwierdza, że nie wypada się chlubić, ale odnosząc wszystko do Boga, zaleca, by także Jemu przypisywać to dobro, jakie można, a czasem trzeba powiedzieć o sobie, swoim doświadczeniu i pracy.

Rzeczownik apostolus występuje poza cytowanymi fragmentami jedenaście razy: „Dlatego przedłuża nam dni tego żywota, by dać nam czas na poprawę z grzechów, według słów Apostoła: Czy nie wiesz, że Boża cierpliwość prowadzi cię do pokuty" (Prolog 36-37, odpowiada RM Komentarz do Psalmów 36-37, cytuje Rz 2, 4).

W rozdziale o opacie: „Wierzymy, ze w klasztorze zastępuje Chrystusa, skoro nosi taką nazwę, jaką dajemy Panu, zgodnie ze słowami Apostoła: Otrzymaliście duch a przybrania za synów $i$ w tym duchu wołamy: Abba, Ojcze" (2, 2-3; odpowiada RB 2, 2-3, cytuje Rz 8, 15). Niektórzy dyskutowali, czy nie jest to przypisanie Chrystusowi tego, co należy się tylko Bogu Ojcu, ale wydaje się, że Syn uczestniczy we wszystkim we władzy Boga Ojca, a przełożony w klasztorze zastępuje Boga - Jedynego w Trójcy, Ojca, a szczególnie Syna, który stał się człowiekiem i wskazał nam drogę życia. Św. Benedykt przekazuje tu starszą tradycję, poświadczoną przez Regutę Mistrza.

W rozdziale o pokorze: „Trzeci stopień pokory osiaga ten, kto z miłości Boga poddaje się przełożonemu, z całym posłuszeństwem naśladując Pana, o którym Apostoł mówi: Stat się postusznym aż do śmierci" (7, 34 odpowiada RM 10, 49, cytuje fragment hymnu o uniżeniu i wywyższeniu Flp 2, 8. W RM o trzecim stopniu autor mówi w tekście obejmującym wersety 45-51 z odniesieniami także do 1 Kor 6,12 . Św. Benedykt wybrał to, co najważniejsze z tekstu pobożnego, ale może nieco rozwlekłego). 
W rozdziałach o liturgii godzin jest kilka wzmianek o czytaniu Apostoła $(9,10$ - odmówione z pamięci po psalmach drugiego nokturnu wigilii nocnych; 13, 11 - w jutrzni dni powszednich). Odpowiednie teksty Reguty Mistrza mówią o czytaniu Apostoła przez przełożonych (46, 3.5-6) podczas jutrzni $(35,1)$, prymy, tercji, seksty i nony $(35,3 ; 40,3)$, modlitwy wieczornej $(36,1 ; 41,3)$, komplety $(37,2)$ i oficjum nocnego $(44,3.8)$, a w rozdziale o jutrzni ogólnie wspominają czytania $(39,3)$ bez określenia, z jakich tekstów poza ewangelią $(39,3)$, którą zawsze czyta opat, jeśli jest obecny $(35,1 ; 36,1 ; 37,2 ; 39,2 ; 40,3 ; 41,3 ; 44,4 ; 46,4-7)$.

W rozdziale o cięższych przewinieniach: „Niech będzie samotny w naznaczonej mu pracy, trwając w żałobie pokuty i rozważając owe straszliwe słowa Apostoła: Taki człowiek został wydany na zatracenie ciała, aby dusza jego byta zbawiona $w$ dniu Pańskim" (25, 3-4 cytuje 1 Kor 5, 5- jest to własny tekst RB, znacznie krótszy i bardziej konkretny od bardzo obszernych, zawierających wiele obrzędów pokutnych i przemówień opata tekstów RM 12-14 o karze wyłączenia ze wspólnoty).

W rozdziale: „Jak opat ma się troszczyć o wyłączonych ze wspólnoty” czytamy: „Jak mówi Apostoł: Trzeba wzmocnić miłość ku niemu, więc niech wszyscy za niego się modlą" (27, 4, aluzja do 2 Kor 2, 8 - indeks biblijny do polskiego wydania nie podaje odniesień do tego tekstu w RM).

W rozdziale „o braciach, którzy często upominani nie chcą się poprawić”: „Jeżeli i w ten sposób nie będzie uleczony, niech opat użyje żelaza do cięcia, jak mówi Apostoł: Usuńcie zło spośród was, i znowu: Jeśli niewierny odchodzi, niech odejdzie, aby jedna owca chora nie zaraziła całej trzody" (28, 5-6, cytowane 1 Kor 5, 13 i 7, 15 - indeks biblijny do polskiego wydania nie podaje odniesień do tych tekstów w RM).

W rozdziale o codziennej ręcznej pracy autor zamieścił odwołanie się do przykładu dawnych mnichów i apostołów: „Wtedy bowiem są naprawdę mnichami, gdy żyją z pracy rąk własnych, jak Ojcowie nasi i Apostołowie" $(48,8)$. Odpowiadający temu pouczeniu rozdział $50 \mathrm{RM}$ zawiera dłuższe wprowadzenie z biblijnymi przykładami: „Bezczynny pracuje dla śmierci i jest zawsze pod wpływem pożądań” (w. 2, por. Prz 13, 4 wg LXX i 2 Kor 7,1) oraz: „Ponadto Apostoł mówi: Gdy byliśmy u was, nakazywaliśmy wam to: kto nie chce pracować, niech też nie je" (w. 6 cytuje 2 Tes 3, 10 -w indeksie do łacińskiego wydania RB 18, 8 uznano za aluzję do 2 Tes 3, 10-12). U św. Benedykta jest odwołanie ogólnie do przykładu apostołów, ale dane Nowego Testamentu wskazują, że pracą ręczną w okresie posługi apostolskiej zajmowali się konkretnie przede wszystkim św. Paweł i Barnaba (por. 1 Kor 9, 6). RM o pracy św. Pawła mówi też w rozdziale o przyjmowaniu do klasztoru kapłanów, cytując 1 Kor 4, 12 i 2 Tes 3, 8. 10 (RM 83, 14-16). 
W rozdziale o odzieniu i obuwiu braci autor uczy: „Niech opat zawsze bierze pod uwagę owo zdanie z Dziejów Apostolskich: Dawano każdemu, czego potrzebowat" $(55,20)$. W łacińskim tekście nazwa księgi zawiera formę rzeczownikową, cytat z Dz 4, 35 pokazuje troskę o potrzeby wszystkich członków wspólnoty. W RM 87, 14-15 jest cytat z Dz 4, 34 i aluzja do 4, 35 dotyczące sprzedania własności i złożenia jej u stóp apostołów w przemówieniu opata do brata wstępującego do klasztoru, który powinien wyrzec się wszelkiej własności i przekazać ją klasztorowi

Rozdział o sposobie przyjmowania braci zaczyna się słowami: „Niech nie zezwala się łatwo na wstąpienie temu, który przychodzi do klasztoru; należy uczynić tak, jak każe Apostoł: Wypróbujcie duchy, czy sa z Boga" (58, 1-2). Cytat pochodzi z Pierwszego Listu św. Jana (1 J 4, 1). W RM zastosowano go w długim rozdziale zatytułowanym: „Po wstąpieniu do klasztoru świecki nie powinien zmieniać ubrania ani otrzymywać tonsury przez rok” w związku z potrzebą poddania kandydata próbie: „Przeto, gdy tak łatwo wszedł (do klasztoru), nie powinno się mu wierzyć, aż się okaże, iż czynami wypełnił to, co przyrzekł słowami, jak mówi Pismo: Nie wierzcie każdemu duchowi, lecz najpierw próbujcie" $(90,71)$.

Widzimy, że w wielu wypadkach „apostoł” bez imienia oznacza św. Pawła (raz św. Jana), służy do wprowadzenia cytatu z jego listów albo podania za przykład jego życia i postępowania.

Przymiotnik apostolicus w łacińskim tekście Reguły św. Benedykta występuje dwa razy:

W rozdziale ,jaki powinien być opat”: „W swoim nauczaniu opat powinien zawsze stosować się do wskazówki Apostoła, mówiącego: Upominaj, proś $i$ gań" (In doctrina sua namque abbas apostolicam debet illam semper formam seruare, in qua dicit: Argue, obsecra, increpa -2, 23, odpowiada RM 2, 23, cytuje 2 Tm 4, 3, tekst z Corpus Paulinum). W polskim przekładzie przez rzeczownik oddano przymiotnik ,apostolski”, odwrotnie niż w tytule Dziejów Apostolskich (RB 55, 20), których łacińską formę tytułu dokładnie trzeba by oddać przez „Dzieje” lub „Czyny Apostołów”.

W rozdziale o szafarzu klasztornym: „Niech czuwa nad własną duszą, pamiętając zawsze o słowach apostolskich: Kto dobrze stuży, zyska dla siebie dobry stopień" (31, 8 cytuje $1 \mathrm{Tm} 3,13$ - indeks biblijny do polskiego przekładu RM nie zawiera odniesienia do tego tekstu). „Słowa apostolskie” to tekst z Corpus Paulinum.

Cytaty i aluzje do tekstów związanych ze św. Pawłem są w Regule św. Benedykta liczne. Indeks z wydania R. Hanslika podaje 69 wersetów Corpus Paulinum, do których są odniesienia w Regule. Według przyjętej tam klasyfikacji cytowanych jest 30 wersetów, aluzje są do 39. Łącznie odniesienia 
są w 82 miejscach Reguty. Dla porównania odniesienia są do 66 wersetów Ewangelii, w tym jak w czasach patrystycznych najwięcej do św. Mateusza (39 - cytowane 16 tekstów, reszta aluzje w 46 tekstach RB), potem do św. Łukasza (21 - cytaty 4 tekstów, aluzje do 17 w 24 tekstach RB), a tylko po 3 do św. Marka (aluzje w 3 tekstach RB) i św. Jana ( 2 cytaty i aluzja w 4 tekstach RB) - razem w 79 miejscach RB. Z tekstów Pawłowych z Listu do Rzymian są cytaty z 7 i aluzje do 4 wersetów w 13 miejscach RB; z Pierwszego Listu do Koryntian cytaty 6 tekstów i aluzje do 12 w 22 miejscach RB; z Drugiego Listu do Koryntian są cytaty z 4 miejsc i aluzje do 3 w 7 miejscach RB; z Listu do Galatów 2 cytaty i 3 aluzje w 5 miejscach RB; z Listu do Efezjan jeden cytat i aluzje do 4 tekstów w 6 miejscach RB; z Listu do Filipian dwukrotnie cytowany jest jeden werset $(2,8)$, do trzech innych są aluzje (do każdego raz); z Listu do Kolosan raz cytowany jest jeden werset; z Pierwszego Listu do Tesaloniczan cytowane są 2 wersety i aluzje do czterech miejsc w 6 miejscach RB; raz jest aluzja do jednego tekstu z Drugiego Listu do Tesaloniczan (3, 10-12); z Pierwszego Listu do Tymoteusza dwa wersety są cytowane - jeden dwa, drugi trzy razy - oraz są aluzje do pięciu innych wersetów (do każdego raz); jest jedna aluzja do wersetu z Listu do Tytusa i trzy do Listu do Hebrajczyków uważanego wtedy za dzieło św. Pawła.

Indeks do polskiego wydania nie rozróżnia miedzy cytatami i aluzjami. Podaje następujące liczby: Ewangelia św. Mateusza - odniesienia do 30 tekstów w 34 miejscach RB; Ewangelia św. Łukasza - odniesienia do 18 tekstów w 19 miejscach RB; Ewangelia św. Marka - odniesienia do 3 tekstów w 3 miejscach RB; Ewangelia św. Jana - odniesienia do 2 tekstów w 3 miejscach RB; List do Rzymian - odniesienia do 10 tekstów w 12 miejscach RB; Pierwszy List do Koryntian - odniesienia do 17 tekstów w 17 miejscach RB; Drugi List do Koryntian - odniesienia do 4 tekstów w 4 miejscach RB; List do Galatów - odniesienia do 3 tekstów w 3 miejscach RB; List do Efezjan odniesienia do 4 tekstów w 4 miejscach RB; List do Filipian - odniesienia do 2 tekstów w 2 miejscach RB; Pierwszy List do Tesaloniczan - odniesienia do 3 tekstów w 3 miejscach RB; Pierwszy List do Tymoteusza - odniesienia do 4 tekstów w 4 miejscach RB; Drugi List do Tymoteusza - jedno odniesienie do jednego tekstu; List do Hebrajczyków - 3 odniesienia do 3 tekstów.

Porównując w Regule św. Benedykta częstotliwość odniesień do Ewangelii i Corpus Paulinum, widzimy, że ten drugi zestaw pism według pierwszego indeksu był wykorzystywany nieznacznie częściej (66/79 i 69/82), według indeksu polskiego - nieco rzadziej (53/59 i 51/53). W Regule Mistrza według indeksu biblijnego do polskiego przekładu są 143 odniesienia do 94 tekstów Ewangelii św. Mateusza, 7 do 7 tekstów Ewangelii św. Marka, 49 do 33 tekstów Ewangelii św. Łukasza i 15 do 12 tekstów Ewangelii św. Jana. Dla 
tekstów Pawłowych statystyka przedstawia się następująco: 33 odniesienia do 25 tekstów Listu do Rzymian, 29 do 20 tekstów Pierwszego Listu do Koryntian, 10 do 10 tekstów Drugiego Listu do Koryntian, 21 do 15 tekstów Listu do Galatów, 25 do 14 tekstów Listu do Efezjan, 9 do 6 tekstów Listu do Filipian, 3 do 3 tekstów Listu do Kolosan, 7 do 5 tekstów Pierwszego Listu do Tesaloniczan, 5 do 3 tekstów Drugiego Listu do Tesaloniczan, 8 do 4 tekstów Pierwszego Listu do Tymoteusza, 6 do 3 tekstów Drugiego Listu do Tymoteusza i jedno do jednego tekstu Listu do Tytusa. Razem daje to 214 odniesień do 145 tekstów Ewangelii i 145 odniesień do 104 tekstów Corpus Paulinum. Jeśli weźmie się pod uwagę, że Reguła Mistrza jest mniej więcej trzykrotnie dłuższa od Reguły św. Benedykta, z zestawienia wynika, że w stosunku do swej objętości RB nieco częściej odwołuje się do tekstów Pawłowych, natomiast RM do Ewangelii. Zawiera ona wiele formuł przemówień opata, w których odwołuje się do Pisma Świętego.

Odniesienia do Dziejów Apostolskich według indeksu w polskim wydaniu obejmują fragmenty, w których św. Paweł się jeszcze nie pojawia, natomiast indeks łacińskiego krytycznego wydania widzi aluzję do Dz 28, 1 w RB 53, 9: „pełna uprzejmość”, jaką należy okazać gościom, odpowiada niespotykanej życzliwości, jaką św. Paweł i jego towarzysze podróży doznali na Malcie po rozbiciu okrętu. Łacińskie słowo humanitas (gr. $\phi\llcorner\lambda \alpha \nu \theta \rho \omega \pi i \alpha$ ) dobrze oddaje też podstawową cechę Reguły otwartej na każdego człowieka.

Omówimy teksty zastosowane częściej niż raz w Regule, by zobaczyć, jak rozumiał je Patriarcha Mnichów Zachodu.

\section{Teksty Pawłowe, do których jest najwięcej odniesień w Regule św. Benedykta}

Rz 2, 11 zacytowano w drugim rozdziale RB „Jaki winien być opat”: „bo czy wolny czy niewolnik wszyscy jesteśmy jedno w Chrystusie i pod jednym Panem pełnimy jednakową służbę wojskową, gdyż Bóg nie robi różnicy między ludźmi" (2, 20, odpowiada RM 2, 19, przed Rz 2, 11 cytuje też Ef 6, 8; Ga 3, 28, oraz RM 93, 88 wśród pouczeń dla nowego opata, obok odniesienia do $2 \mathrm{Tm} \mathrm{4,8);} \mathrm{aluzja} \mathrm{do} \mathrm{tego} \mathrm{tekstu} \mathrm{jest} \mathrm{w} \mathrm{rozdziale} \mathrm{zatytułowanym:}$ „Czy wszyscy mają otrzymywać rzeczy potrzebne w tej samej ilości”: „Nie mówimy, aby niektórym osobom okazywać szczególne względy, co niech się nie zdarza, lecz aby brać pod uwagę słabość" $(34,2)$.

$\mathrm{Rz} 12,10$ zastosowano w rozdziale „O zachowaniu należnego miejsca w zgromadzeniu”: „Gdy bracia się spotykają, niech młodszy prosi starszego o błogosławieństwo. Gdy starszy nadejdzie, młodszy ma powstać i ustąpić mu miejsca, aby usiadł. I niech sam nie siada, póki go starszy nie 
zaprosi. W ten sposób będzie spełnione to, co napisano: Nawzajem uprzedzajcie się w uprzejmości" (63, 15-17). W RM ten cytat jest w rozdziale „W jaki sposób powinni domowi bracia pozdrawiać przychodzących z zewnątrz" $(65,8)$. Dwie aluzje do tego tekstu są w przedostatnim rozdziale RB: „O dobrej gorliwości, którą mnisi mają okazywać”: „Taką gorliwość winni praktykować mnisi z żarliwą miłością, a zatem mają okazywać sobie szacunek z uprzedzającą grzecznością [...] Czystą miłość braterską będą sobie okazywali" (72, 3-4. 8).

1 Kor 4, 12 zastosowano w dwóch tekstach z pierwszej części Reguty, w rozdziałach „Jakie są narzędzia dobrych uczynków” i „O pokorze” jako cecha czwartego stopnia, w cytowanym już tekście wymieniającym imię św. Pawła: „Złorzeczącym nie złorzeczyć nawzajem, lecz właśnie ich błogosławić” (4, 32, odpowiada RM 3, 37); „z Apostołem Pawłem znoszą fałszywych braci i błogosławią złorzeczącym” (7, 43, odpowiada RM 10, 60; pierwsza część wersetu 4, 12 podana też jest jako przykład pracy św. Pawła w RM 83, 15).

Również w pierwszej części Reguły są odniesienia do 1 Kor 9, 27: „Niech jego (opata) czyny uczą, że nie należy robić tego wszystkiego, co jako naganne uczniom swoim przedstawił, aby nie okazał się godnym potępienia ten, który głosił kazania dla innych” (2, 13, odpowiada RM 2, 13); „Ciało umartwiać" (w pierwszych słowach tego wersetu św. Paweł pisze, że poskramia swe ciało - 4, 11, odpowiada RM 3,11).

Tekst 1 Kor 10, 4, w którym św. Paweł nawiązuje do starotestamentowego nazywania Boga Skałą i odnosi je do Chrystusa, zastosowano w dwóch tekstach z początkowej części Reguły: „Kto złośliwego diabła, czymkolwiek by go kusił, razem z jego pokusami, gdy tylko się narodzą, odpychając od oczu swego serca, wniwecz obraca, a wymysły jego za nic ma i o Chrystusa rozbija” (Prolog 28, odpowiada RM Komentarz do Psalmów 24, gdzie jest wyraźne utożsamienie skały z Chrystusem: „o Chrystusa - skałę rozbija”); "Złe myśli do serca przychodzące natychmiast o Chrystusa rozbijać i odkrywać je ojcu duchownemu" (4, 50, odpowiada RM 3, 56 bez drugiej części o odkrywaniu złych myśli ojcu duchownemu).

Aluzje do Ef 4, 27 o dawaniu miejsca czy okazji diabłu są w drugiej części Reguty, w rozdziałach „O spóźniających się do chóru albo do stołu” i „Czy wolno mnichowi przyjmować listy lub inne przedmioty”: „Bo gdyby zostawali poza kościołem, mógłby się znaleźć taki, który by się położył i usnął albo, siedząc poza kościołem, zajął się plotkami i nastręczył sposobność dla złego ducha” $(43,8)$; „A brat ów niech się nie smuci, aby diabłu nie dawać sposobności" $(54,4)$. RM również wykorzystuje ten tekst w innym kontekście, wśród przestróg dla szafarza $(16,64)$. 
Fragment Flp 2, 8 o udziale mnicha w uniżeniu Chrystusa jako drodze do udziału w Jego wywyższeniu Reguła stosuje w zakończeniu prologu i w związku z trzecim stopniem pokory: „Abyśmy, nie odstępując nigdy od tego nauczania i pozostając $w$ tej nauce aż do śmierci w klasztorze, zasłużyli przez cierpliwość być uczestnikami męki Chrystusa, aby Pan uczynił nas wspótdziedzicami Jego królestwa. Amen" (Prolog 50, razem z 1 P 1, 13; Rz 8, 17, odpowiada zakończeniu Komentarza do Psalmów, ostatniej części wstępu do RM nazwanego Tematem); „,Trzeci stopień pokory osiąga ten, kto z miłości Boga poddaje się przełożonemu, z całym posłuszeństwem naśladując Pana, o którym Apostoł mówi: Stat się postusznym aż do śmierci” (7, 34, opowiada RM 10, 49, gdzie o tym stopniu jest znacznie więcej: 10, 45-52).

Reguła św. Benedykta w drugiej części, znacznie mniej podobnej do Reguły Mistrza, wykorzystuje także teksty z Listów Pasterskich, szczególnie do Tymoteusza. Są dwa odniesienia do $1 \mathrm{Tm} 3$, 13, w rozdziałach o szafarzu i o wyborze opata: „Niech czuwa nad własną duszą, pamiętając zawsze o słowach apostolskich: Kto dobrze stuży, zyska dla siebie dobry stopień" $(31,8)$; ,aby po dobrej służbie usłyszał od Pana to, co dobry sługa, który w odpowiednim czasie rozdzielał pszenicę swoim towarzyszom: Zaprawdę, powiadam wam, ustanowi go nad całym swoim dobytkiem" (64, 21-22 z cytatem z Mt 24, 47).

Trzy razy Reguła odwołuje się do 1 Tm 5, 20 w związku z karami w rozdziałach „O wyłączeniu ze wspólnoty z powodu win”, „O codziennej pracy ręcznej” i „niech nikt nie odważy się bić winnych”: „Jeśli się nie poprawi, trzeba mu udzielić publicznej nagany wobec wszystkich” (23, 3); „Jeśli się nie poprawi, niech podlega karze według Reguły, aby inni się lękali” (48, 20); „Tych, którzy dopuszczają się wykroczeń, należy upominać wobec wszystkich, aby inni lękali się grzeszyć" $(70,3)$.

Dwa razy są odniesienia do $2 \mathrm{Tm} 4,2$-w rozdziałach o opacie i o przyjmowaniu kandydatów: „W swoim nauczaniu opat powinien zawsze stosować się do wskazówki Apostoła, mówiącego: Upominaj, proś i gań” (2, 23, cytat niepełny, odpowiednik w RM 2, 23) i aluzja: „Jeśli nadal trwać będzie, trzeba go odprowadzić do wspomnianej izby nowicjuszy i znowu będzie się wypróbowywać jego cierpliwość wszelkimi sposobami” $(58,11)$.

Autor Reguly umiał korzystać ze skarbca Pisma Świętego i przekazywać jego naukę jako normę życia dla swoich uczniów i naśladowców.

\section{Podsumowanie}

Życie mnisze jest konsekwentnym wypełnianiem zobowiązań wynikających z chrztu, naśladowaniem Chrystusa i podążaniem do pełnego 
zjednoczenia z Nim. Tradycja mnisza, której wyrazem jest Reguła św. Benedykta, oparta w znacznej mierze na wcześniejszym anonimowym dokumencie, pokazuje, jak mnisi Wschodu i Zachodu czytali i korzystali z Pisma Świętego. W Roku św. Pawła zwróciliśmy szczególną uwagę na jego teksty często przypominane w Regule. Pokazują one, jak mądrość Apostoła Narodów, wielkiego Mistrza chrześcijańskiego życia, może kształtować roztropne postępowanie mnichów i wszystkich chrześcijan starających się dobrze wypełnić swoje powołanie.

\section{Wskazówki bibliograficzne}

- WYBRANE KOMENTARZE DO LISTÓW ŚW. PAWŁA

C. K. Barrett, A Commentary on the First Epistle to the Corinthians, London $1973^{2}$ (Black's New Testament Commentaries).

E. Dąbrowski, Listy do Koryntian. Wstęp - przekład z oryginatu - komentarz, Poznań 1965

(Pismo Święte Nowego Testamentu, 7).

M. Dibelius, H. Conzelmann, A Commentary on the Pastoral Epistles, Philadelphia 1984 (Hermeneia).

A. Jankowski, Listy więzienne świętego Pawła. Wstęp - przekład z oryginału - komentarz ekskursy, Poznań 1962 (Pismo Święte Nowego Testamentu, 8).

J. Gnilka, Der Epheserbrief, Freiburg-Basel-Wien $1977^{2}$ (Herders Theologischer Kommentar zum Neuen Testament, 10.2).

J. Gnilka, Der Philipperbrief, Freiburg-Basel-Wien 1968 (Herders Theologischer Kommentar zum Neuen Testament, 10.3).

K. Romaniuk, List do Rzymian. Wstęp - przekład z oryginału - komentarz, Poznań-Warszawa 1978 (Pismo Święte Nowego Testamentu, 6.1).

M. Rosik, Pierwszy List do Koryntian. Wstęp, przekład z oryginatu, komentarz, Częstochowa 2009 (Nowy Komentarz Biblijny, Stary Testament, 2).

H. Schlier, Der Römerbrief, Freiburg-Basel-Wien 1977 (Herders theologischer Kommentar zum Neuen Testament, 6).

J. Stępień, Listy do Tesaloniczan i Pasterskie. Wstęp - przekład z oryginatu - komentarz, Poznań-Warszawa 1979 (Pismo Święte Nowego Testamentu, 9).

A. Viard, Saint Paul Épittre aux Romains, Paris 1975 (Sources Bibliques).

- NAJWAŻNIEJSZE ZACHODNIE WYDANIA I KOMENTARZE

DO REGU YY BENEDYKTA I REGUEY MISTRZA

A. Böckmann, Perspektiven der Regula Benedicti. Ein Kommentar zum Prolog und den Kapiteln 53, 58, 72, 73, Münsterschwarzach 1986.

Die Benediktusregel, hrsg. im Auftrag der Salzburger Äbtekonferenz, Beuron 19962 .

R. Hanslik, Benedicti Regula, Vindobonae 1977 (Corpus Scriptorum Ecclesiasticorum Latinorum, 75).

I. Herwegen, Sinn und Geist der Benediktinerregel, Einsiedeln 1944.

G. Hozherr, Die Benediktsregel. Eine Anleitung zu christlichem Leben, Düsseldorf $2000^{5}$.

T. G. Kardong, Benedict's Rule. A Translation and Commentary, Collegeville 1996.

A. Lentini, San Benedetto. La Regola, Monte Cassino 1980².

M. Puzicha, Kommentar zum Benediktusregel, mit einer Einführung von C. Schütz, im Auftrag der Salzburger Äbtekonferenz, St. Ottilien 2002. 
The Rule of St. Benedict in Latin and English with Notes, ed. T. Fry, Collegeville 1980.

B. Steidle, Die Regel Benedikts, Beuron $1952^{2}$.

A. Steidle, Die Benediktusregel, Beuron $1984^{4}$.

H. Vanderhoven, P. Masai, P. B. Corbett, La Règle du Maître. Edition diplomatique des manuscrits latins 12205 et 12634 de Paris, Bruxelles-Paris-Anvers-Amsterdam 1953.

A. de Vogüé, La communauté et l'abbé dans la Règle de saint Benoît, Paris 1961.

A. de Vogüé, La Règle de saint Benoît. Commentaire historique et critique, t. 1-6, Paris 1971-1972; La Règle de saint Benoît. Commentaire doctrinal et spirituel, t. 7, Paris 1977, (Sources Chrétiennes 181-186).

A. de Vogüé, La Règle du Maître, t. 1-2, Paris 1964 (Sources Chrétiennes, 105-106).

J.-M. Clement, J. Neufville, D. Demeslay, La Règle du Maître, III. Concordance verbale du texte critique conforme all'orthographe du manuscrit Par. Lat. 12205, Paris 1965 (Sources Chrétiennes, 107).

\section{- PUBLIKACJE W JEZZYKU POLSKIM NA TEMAT ŚW. BENEDYKTA I ŻYCIA MNISZEGO}

„Aby we wszystkim Bóg byt uwielbiony”. Rozważania monastyczne, pr. zb., przygotowali benedyktyni tynieccy, Tyniec 1984.

Św. Benedykt z Nursji, Reguła; św. Grzegorz Wielki, Dialogi. Księga Druga, Kraków 1994.

O. Casel, Święty Benedykt z Nursji mąż Ducha, Kraków 1998.

T. M. Dąbek, Św. Benedykt z Nursji, Kraków 2004 (Wielcy Ludzie Kościoła).

T. M. Dą̧ek, Wokót Reguty św. Benedykta, Kraków 2009.

A. Grün, A. Seuferling, Życie w rytmie stworzenia, Kraków 2000.

E. M. Heufelder, G. Braso, Droga ku Bogu wedtug Reguly św. Benedykta, Tyniec [1982].

G. Holzherr, Reguła Benedyktyńska w życiu chrześcijańskim, Tyniec 1988.

A. Jankowski, Życie mnisze, t. 1-2 (nr 6-7), Kraków 1994.

Medalik świętego Benedykta, opr. S. M. Hiżycki, Kraków $2001^{2}$.

Mnich benedyktyński, Misterium życia monastycznego, Kraków 1996.

Reguła Mistrza, Reguła św. Benedykta, Kraków 2006 (Źródła Monastyczne, 40; Starożytność, 27; Zachodnie Reguły Monastyczne, 1).

B. Rollin, Jak żyć dzisiaj „Reguła” św. Benedykta, Kraków 2001.

P. Sczaniecki, Święty Benedykt, Kraków 2000³.

Stuchaj, módl się, pracuj, red. K. Janicki, Poznań 1989.

Szkoła stużby Pańskiej, pr. zb., Tyniec 1982.

M. Starowieyski, red. E. Stanula, Starożytne reguly zakonne, Warszawa 1980 (Pisma Starochrześcijańskich Pisarzy, 26).

E. de Waal, Szukanie Boga. Droga św. Benedykta, Kraków 1998.

Za przewodem Ewangelii. Profesja monastyczna, red. K. Janicki, Tyniec 1986.

TOMASZ M. DABEK OSB

\section{Słowa kluczowe}

Św. Paweł - życie, dzieło, listy, Reguła św. Benedykta, Reguła Mistrza

\section{Summary}

The references to St. Paul's person and texts in The Rule of St. Benedict

The Rule of St. Benedict is norm of the life for Christian monks in Occident. According to the biblical index in the edition of R. Hanslik (Corpus Scriptorum Ecclesiasticorum 
Latinorum, 75) in the Rule are citations from 30 and allusions from 39 texts of Corpus Paulinum in 82 places of RB. More of one time are citations or allusions to Rom 2, 11; 12, 10; 1 Cor 4, 12; 9, 27; 10, 4; Eph 4, 37; Phil 2, 8; 2 Tim 3, 13; 5, 20; 2 Tim 4, 2. This is a good example of reading and use of the Bible in ancient monasticism and also help for contemporary monks and nuns.

\section{Keywords}

St. Paul's life, work and letters, the Rule of St. Benedict, the Rule of the Master 